\title{
Positive Impact of Balinese Folktale Literacy Learning Students' Social Attitudes and Reading Ability
}

\author{
Made Gautama Jayadiningrat ${ }^{1 *}$, Ni Komang Widiani ${ }^{2}$ iD \\ ${ }^{1}$ Universitas Hindu Negeri I Gusti Bagus Sugriwa, Denpasar, Indonesia \\ ${ }^{2}$ Universitas Pendidikan Ganesha, Singaraja, Indonesia \\ *Corresponding author: madegautamajayadiningrat@uhnsugriwa.ac.id
}

\begin{abstract}
This paper reports the effect of Balinese folktale literacy learning on elementary students' reading ability and social attitudes. The type of research is pseudo-experimental research with a non-equivalent post-test-only control group design. The population in this study was 129 students. The sample was selected by using random sampling techniques. 23 students were treated as an experimental group and 27 students were treated as a control group. The data were obtained by administering multiple-choice tests and distributing questionnaires. The data were analyzed by using descriptive statistical analysis techniques and inferential statistics, i.e., Manova-test. The data of this study were also described through the classification level of each data group by using five conversion guidelines. The results showed that there was a significant difference between the reading ability and the social attitudes of the students taught by using folktale literacy learning and those who were taught by using conventional learning. It can be seen from the Sig. $<$ value of 0.05 . Based on these results, it can be concluded that Balinese folktale literacy learning affected reading ability and social attitudes of elementary students.
\end{abstract}

Keywords: Literacy; Reading Comprehension; Social Attitudes

$\begin{array}{lll}\text { History: } & & \text { Publisher: Undiksha Press } \\ \text { Received } & : \text { 10 August } 2020 & \text { Licensed: This work is licensed under } \\ \text { Revised } & : \text { 12 September } 2020 & \text { a Creative Commons Attribution 3.0 License } \\ \text { Accepted } & : 26 \text { December } 2020 & \text { CC C) OP } \\ \text { Published } & : 25 \text { April } 2021 & \end{array}$

\section{Introduction}

Education is an essential element to face the globalization era. This is because education can produce a nation, which has good characters such as innovative, skilled, and creative (Apriana, Y., Wahyuningsih, \& Samudera, 2020; Ikhwan, Farid, Rohmad, \& Syam, 2020; Wildan, Hakim, Siahaan, \& Anwar, 2019). This is in line with the objective of education, that is, to shape the nation's character and civilization (Hidayat \& Syam, 2020; Wijayanti \& Sulaksono, 2019). One of the efforts to educate the nation's life is by strengthening social character and attitude through education. The importance of shaping students' character through the cultivation of social attitudes in terms of honesty, discipline, responsibility, care (tolerance, mutual assistance), manners, confidence in interacting with the social and natural environment effectively as stated in the core competencies of the curriculum 2013 (Purwaaktari, 2015; Zahary, Bharata, \& Sutiarso, 2017). The characters and social attitudes of the students can be built up starting from practicing one's language skills such as reading (Cakra, Dantes, \& Widiartini, 2016; Suwartiningsih, Purwadi, \& Pusari, 2018).

Considering that fostering the reading literacy movement for elementary school students is not easy, cooperation from various parties such as parents, teachers, and schools is 
needed (Duriawati, Wasliman, Mulyanto, \& Barlian, 2020; Fikriyah, Rohaeti, \& Solihati, 2020; Karadağ, 2014). Reading for students also plays a role in knowing the various advances in science and technology that continue to evolve. Through reading, the advancement of science and technology can be learned and understood before it can be applied (Akbar, 2017; Zidoun, El Arroum, Talea, \& Dehbi, 2016). Reading is one of the four basic language skills and is a part or component of written communication. Reading ability is the ability to understand the content of the text as a whole, have the speed of reading, and apply effective reading techniques (Din, 2020; Harni, 2020; Kim \& Hannafin, 2011). To achieve the educational objectives, especially in reading skills, the government has made various efforts. One of the efforts made was releasing Ministerial Regulation No. 23 of 2015. The Ministerial Regulation contains the growth of ethics including the School Literacy Movement (Gerakan Literasi Sekolah). This policy requires students to read non-learning books for 10-15 minutes before learning begins. The effort has been conducted periodically and intensively. However, the problem has not been solved yet. In other words, more innovative efforts are still needed for the implementation of education reform.

Integrating reading activity in Indonesian subjects has not been conducted effectively. Teachers are less creative in creating conditions that direct students to integrate their daily life experience outside the classroom to construct their knowledge in the school. This condition caused students difficulty in understanding the texts. As a result, the goals of Indonesian learning has not been achieved successfully (Andayani \& Arono, 2018; Khusniyah \& Hakim, 2019). Based on the results of the reading test and the writers' observation, it was shown that the ability to read Indonesian language elementary school students of Cluster IV in Kubu subdistrict is still inadequate. The score on students' Indonesian reading comprehension tests was still low. Additionally, they also had less interest in reading. These conditions, indeed, worsens the quality of education.

From the writers' observation in the field, low student understanding is likely to cause misunderstanding or misconception among students. The complexity of student misconceptions indicates that the learning process of Bahasa Indonesia, especially in elementary schools in general is not optimal. The low achievement toward reading led to having students' misconception. This condition might be caused by the traditional ways of learning. In addition to the low of students' achievement toward reading, some problems are also existing such as the characters' degradation, individualism, intolerance, and irresponsibility. Nowadays, people tend to be individualists, more concerned with their own lives. Students tend to be irresponsible, unable to work in teams, and unable to respect others. Based on the results of document analysis, the reading ability and the social attitudes of students were relatively low.

Based on the above problems, teachers as educators need to develop students' social attitudes and reading skills in Bahasa Indonesia (Hidayati, 2020). Education will be successful if the learning involves student participation. One way to improve the results of reading ability to understand Bahasa Indonesia and social attitudes of students then what needs to be done is to change the way students learn by applying Literacy Learning (Nurdiyanti \& Suryanto, 2010). Literacy Learning is implemented in schools as a program of the school literacy movement. In this activity, students are encouraged to read fiction or storybooks, such as folktale. Through reading folktales, students do not only learn to read but also learn cultures and characters. In so doing, reading folktale is suitable to be implemented in this literacy movement (Setyawan et al., 2017).

In this context of the study, the folktales read by the students were focused on Balinese ones. This is because Balinese folktales contain a lot of character values, which can be internalized by students that were mostly Balinese. By so doing, the students can strengthen their identity as Balinese. Literacy is widely defined as the ability to listen, speak, 
read, write, and think that becomes part of literacy itself. Literacy activities concentrate on the ability to obtain information from a book. It is expected that it can improve the social attitude and reading knowledge of students in learning Indonesian. The literacy learning model is a learning model that prioritizes language skills in the learning process (Jamil, 2019). Language skills are related to cultural and media contexts. The basic form of literacy learning is reading, writing, speaking, and listening skills (Purwo, 2019). Thus, it is suitable to be used to improve the social attitudes and reading skills of Indonesian students understanding. Therefore, students must read and listen as a habit through literacy to improve their reading ability to understand Bahasa Indonesia.

This statement is in line with the research conducted by Aisyah (2010), which stated that the application of the literacy learning model could improve the ability to write essays in grade V students of SDN Pakisaji 02, especially writing articles based on experience. Marini, Sulha, \& Hartati, (2020) also found that Balinese folktale texts can improve the ability to write plays in grade XI of SMA Negeri 1 Mendoyo. This was proven by the results of the classical learning outcome that exceeded $75 \%$. Literacy learning is considered more attractive as it contains stories of nuanced Balinese culture. Many Balinese cultures can stimulate students' reading skills and improve students' social attitudes.

This study analyzes Balinese folktale literacy learning on social attitudes and reading ability of Indonesian students, including the effect and contribution of folktale literacy learning to the students' ability to read Bahasa Indonesia.

\section{Materials and Methods}

To achieve the objective of the study, this study applied a quantitative approach. This study is included in the quasi-experimental analysis by using a non-equivalent post-test-only control group design (Daniel, 2016; Sugiyono, 2012). The treatment given in the experimental class is learning that applies a literacy model nuanced Balinese folktale. Control classes were not given special treatment, meaning that the learning applied to the control group is knowing that teachers usually use in daily learning. After being treated, both experimental and control groups were given post-tests to determine social attitudes and students' comprehension in Bahasa Indonesia reading skills in each group. The population in this study was all grade III elementary school students. The total number of the population is 129. To determine the sample of the study, a random sampling technique was administered. This technique was applied because students had been formed in study groups (learning classes or group learning). This random selection of samples was made through a lottery system, which was conducted twice. Based on the results of the draw, 23 students were selected as an experimental group and 27 students as a control class. The total sample count is 50 people. This study involved two variables, namely independent variables, and dependent variables. The independent variable in this study is literacy learning models. Meanwhile, the dependent variables are Balinese folktale, social attitudes and the ability to read Indonesian.

The data collection techniques used in this study were questionnaires for social attitudes and tests for comprehension reading ability. The type of social attitude questionnaire instruments that are compiled consists of 30 statements. Several statements consist of positive opinions and negative statements submitted to students. Five answer options follow each statement, namely "strongly disagree," "disagree," "undecided," "agree," and "strongly agree". Objective test instruments are written in multiple-choice form. The accurate test consists of items that can be answered by choosing one of the correct alternatives from several available alternatives (Nurkancana and Sunartana, 1990). Before implementing the research instruments, both instruments were tested for validity and reliability. The results showed that the overall item of the instrument was valid with an average coefficient of 0.808 
for the social attitude questionnaire and 0.93 for the comprehension reading ability test. The reliability of the instrument is calculated using the Alpha-Cronbach formula for the KuderRichardson formula social attitude questionnaire. Reliability analysis showed a coefficient of 0.907 for social attitudes questionnaires and 0.882 for comprehension reading tests. Both instruments are in the category of very high reliability. Data analysis in this study used descriptive and inferential statistical analysis. Hypothesis testing in this study followed the Manova test. Before being analyzed, prerequisite test analysis includes data distribution normality test, variance homogeneity test, multivariate homogeneity test, and variable bound multicollinearity test were administered. Data analysis is performed with the help of the IBM SPSS Statistics 25.0 program.

\section{Results and Discussion Results}

The data of this study is a score of social attitudes and reading ability of Indonesian language understanding as a result of the application of Balinese folktale-nuanced literacy models in experimental groups and conventional learning models in the control group. In gaining an overview of social attitudes and reading skills of Indonesian language understanding, the data were analyzed with descriptive analysis. The results of descriptive analysis are presented in Table 1.

Table 1. Descriptive Data Analysis Results

\begin{tabular}{lcccc}
\hline \multirow{2}{*}{ Statistic } & \multicolumn{2}{c}{$\begin{array}{c}\text { Students' Indonesian Language } \\
\text { Comprehension Reading Skills }\end{array}$} & \multicolumn{2}{c}{ Students' Social Attitude } \\
\cline { 2 - 5 } & $\begin{array}{c}\text { Experimental } \\
\text { Group }\end{array}$ & Control & Experimental & Control \\
& 24.57 & 16.70 & 81.91 & Group \\
Mean & 25 & 16 & 83 & 59 \\
Median & 27 & 15.68 & 86 & 58 \\
Modus & 5.53 & 15.68 & 45.08 & 75.46 \\
Varian & 2.35 & 3.96 & 6.71. & 8.69 \\
Standard Deviation & & & & \\
\hline
\end{tabular}

The prerequisite test of analysis includes data distribution normality test, variance homogeneity test, multivariate homogeneity test, and dependent variable multicollinearity test. The first prerequisite test was a normality test with Kolmogorov-Smirnov. The analysis results showed that all data came from normally distributed data groups. A Sig value can indicate this $\mathrm{P}>0.05$. Once the normality requirement is met, the next prerequisite test is a homogeneity test. In this study, the homogeneity test was conducted with two analyses: variance homogeneity test with Levene's Test of Equality and multivariate homogeneity test with Box's Test of Equality of Covariance Matrices. The results of homogeneity analysis show similar meaning that the data of the research results come from a homogeneous data group. Each test shows a value greater than 0.05. Sig value. Levene's Test of Equality was 0.272 for social attitudes while Sig score of the reading ability was 0.445 . Meanwhile, the homogeneity test with Box's Test of Equality of Covariance Matrices obtained an F value of 0.228 with Sig. 0.880 . The next pre-requisite test is a multicollinearity test aimed at finding out whether or not the symptoms of multicollinearity in each bound variable are analyzed. Multicollinearity test using Tolerance and VIP values. The results showed that tolerance values of 0.849 and VIP were 3.349 , meaning there were no symptoms of multicollinearity between social attitude data and comprehension reading ability. 
Based on the prerequisite test analysis results, all the prerequisites needed to conduct the Manova test have been fulfilled so that the hypothesis test with Manova can be done. The results of the Manova test analysis are presented in Table 2 and Table 3.

Table 2. Multivariant Analysis Results

\begin{tabular}{llccccc}
\hline Effect & & Value & F & Hypothesis df & Error df & Sig. \\
\hline Intercept & Pillai's Trace & 0.994 & $3.458 \mathrm{E}^{\mathrm{a}}$ & 2.000 & 43.000 & 0,000 \\
& Wilks' Lambda & 0.006 & $3.4583^{\mathrm{a}}$ & 2.000 & 43.000 & 0,000 \\
& Hotelling's Trace & 160.852 & $3.4583^{\mathrm{a}}$ & 2.000 & 43.000 & 0,000 \\
& Roy's Largest & 160.852 & $3.458 \mathrm{E} 3^{\mathrm{a}}$ & 2.000 & 43.000 & 0,000 \\
& Root & 0.234 & $6.582^{\mathrm{a}}$ & 2.000 & 43.000 & 0,000 \\
$\mathrm{~A}$ & Pillai's Trace & 0.766 & $6.582^{\mathrm{a}}$ & 2.000 & 43.000 & 0,000 \\
& Wilks' Lambda & 0.306 & $6.582^{\mathrm{a}}$ & 2.000 & 43.000 & 0,000 \\
& Hotelling's Trace & & & & \\
& Roy's Largest & 0.306 & $6.582^{\mathrm{a}}$ & 2.000 & 43.000 & 0,000 \\
\hline & Root & & & & &
\end{tabular}

Table 3. Analysis of Tests of Between-Subjects Effects

\begin{tabular}{lcccccc}
\hline Source & $\begin{array}{c}\text { Dependent } \\
\text { Variable }\end{array}$ & $\begin{array}{c}\text { Type III Sum of } \\
\text { Squares }\end{array}$ & df & Mean Square & F & Sig. \\
\hline Corrected & $\mathrm{X} 1$ & $1083.535^{\mathrm{a}}$ & 1 & 1083.535 & 12.300 & 0.001 \\
Model & $\mathrm{X} 2$ & $285.654^{\mathrm{b}}$ & 1 & 285.654 & 5.727 & 0.001 \\
Intercept & $\mathrm{X} 1$ & 306711.796 & 1 & 306711.796 & $3.482 \mathrm{E} 3$ & 0.000 \\
& $\mathrm{X} 2$ & 307736.088 & 1 & 307736.088 & $6.170 \mathrm{E} 3$ & 0.000 \\
$\mathrm{~A}$ & $\mathrm{X} 1$ & 1083.535 & 1 & 1083.535 & 12.300 & 0.001 \\
& $\mathrm{X} 2$ & 285.654 & 1 & 285.654 & 5.727 & 0.001 \\
Error & $\mathrm{X} 1$ & 3875.943 & 49 & 88.090 & & \\
& $\mathrm{X} 2$ & 2194.716 & 49 & 49.880 & & \\
Total & $\mathrm{X} 1$ & 310666.000 & 51 & & & \\
& $\mathrm{X} 2$ & 309983.000 & 51 & & & \\
Corrected & $\mathrm{X} 1$ & 4959.478 & 50 & & & \\
Total & $\mathrm{X} 2$ & 2480.370 & 50 & & & \\
\hline
\end{tabular}

Note:

X1: Social Attitudes

X2: Comprehension Reading Ability

Based on the results of the Manova analysis that has been presented in Table 3 and Table 4, several findings were obtained. First, the significance score on Pillai's Trace, Wilks' Lambda, Hotelling's Trace, and Roy's Largest Root was 0.000 (<0.05). This shows simultaneous differences in scientific attitudes and science process skills between students who follow the learning with the Balinese folktale-nuanced literacy learning model and the group of students who follow the learning by applying conventional assessments. Second, the results of the Tests of Between-Subjects Effects analysis showed a significance value of $0.001(<0.05)$ for variable X1 (Social Attitudes). This means that part there is a significant influence of learning with the Balinese folktale literacy learning model on the social attitudes of grade III elementary students. Third, the results of the Tests of Between-Subjects Effects analysis showed a significance value of $0.001 \quad(<0.05)$ for variable X2 (Comprehension 
Reading Ability). This means that part there is a significant influence of learning with the Balinese folktale literacy learning model on reading the understanding of grade III elementary students.

\section{Discussion}

The results showed that there was a significant difference in reading ability between students taught with literacy learning nuanced Balinese folktale and trained with conventional learning. In the Indonesian language subjects, literacy learning nuanced Balinese folktale is very appropriate in applying because the subjects of Bahasa Indonesia are closely related to the real world and the environment around the students. Besides students know the subject matter of Bahasa Indonesia, students also increased about the relationship between Bahasa Indonesia lessons and the culture in Bali. The learning experience is an effort to grow the potential of learners to have civic knowledge, civic participation, and civic responsibility (Dharma \& Siregar, 2015). Thus, the student's learning experience is an understanding of the concept of the material taught and able to increase the student's knowledge about the surrounding culture, especially Balinese culture.

The results of this analysis are also proven directly through observation during the learning process. In the experimental class, given the form of literacy, learning nuanced Balinese folktales in Bahasa Indonesia subject made students more excited. It familiarized them to read, dig information, and found concepts by themselves. Students became independent, and students' understanding was also increasing because the reading used as literacy material was integrated with the cultural insights where the students were located, namely Balinese folktale. While in the control class using conventional learning, students looked passive. Students waited for an explanation from the teacher without finding out for themselves about the material being taught. Students were not active in answering teacher questions because students were bored reading the learning materials. The students' inactiveness in findings ways to learn the learning materials had led them to have low achievement.

Literacy learning nuanced Balinese folktale could affect the ability to read and the social attitudes of students. This is proven directly in the learning process. In the experiment class after the implementation of Balinese folktale literacy learning, students were more familiar with the surrounding environment, more actively interact with their friends and teachers, and more confident in expressing opinions with polite and polite language because they had been equipped with how to compose words through the students' experience in reading and learning that had been integrated with the cultural environment where the students live.

Social attitudes become the individual's consciousness that determines the real action, repeated repeatedly towards the social object. Social attitudes have several aspects, including honesty, discipline, tolerance, manners, confidence (Gusviani, 2017). These aspects also create people's perspectives. Culture can shape the attitudes of community members and provides a pattern of experiences of individuals who become community groups. Learning literacy nuanced Balinese folktale affects the ability to read and social attitudes. Balinese folktale literacy learning emphasizes the process of full student engagement through reading to find the learning material and connect it with real-life situations and cultural environments to encourage students to be able to apply it in their lives. Windyariani, S., \& Sutisnawati (2016) stated that literacy is the ability to implement the knowledge that students have to solve problems in real life.

This research is in line with the study conducted by Tantri \& Dewantara (2017) on the effectiveness of literacy culture to improve the reading culture of elementary school students obtaining the results that literacy learning in learning can increase students' 
motivation in knowledge, in addition, students are more confident in performing in front of the class. In addition, similar research is also conducted by Nurdiyanti \& Suryanto (2010) Through science, literacy learning can be applied as a learning strategy that can help students to think critically, especially in science learning, and improve the knowledge of reading skills, especially scientific concepts and technology and social environment of students.

Literacy learning is not only applied in Bahasa Indonesia subjects but also in other subjects. In addition, it is necessary to integrate literacy learning with additional cultural insights or with supporting media that makes students' reading ability improve. Besides increasing students' social attitudes, literacy learning can also increase students' learning motivation. In addition, research on literacy learning can also be integrated with other cultural insights or supporting media to measure students' abilities. Research on literacy learning can be further developed by conducting research with additional cultural insights and varied with more innovative media to make learning more enjoyable and make students better understand the teaching materials delivered by teachers.

\section{Conclusion}

There are simultaneous differences in students' reading ability and social attitudes taught by Balinese folktale nuanced literacy learning models and students who are trained in conventional learning. This is because knowledge with a literacy learning model nuanced Balinese folktale provides students with the opportunity to learn actively. The Balinese folktale literacy learning model contributes to the development of learning at the basic education level to improve the quality of learning.

\section{References}

Aisyah, S. N. (2010). Penerapan model pembelajaran literasi untuk meningkatkan kemampuan menulis karangan siswa di kelas V SDN Pakisaji 02. Universitas Negeri Malang.

Akbar, A. (2017). Membudayakan Literasi Dengan Peogram 6M Di Sekolah Dasar. Jurnal Pendidikan Sekolah Dasar, 3(1), 42-52. https://doi.org/10.30870/jpsd.v3i1.1093.g2690.

Andayani, T., \& Arono. (2018). Improving Students' Ability in Writing Narrative Text By Using Picture Series for the Eight Grade Students of Junior High School. JOALL (Journal of Applied Linguistics \& Literature), 1(2), 1-10. https://doi.org/10.33369/joall.v1i2.4174.

Apriana, Y., Wahyuningsih, S., \& Samudera, W. (2020). Sikap Sosial Dan Kemampuan Berpikir Kreatif Peserta Didik Kimia Sma Berbasis Reading Questioning And Answering Dipadu Creative Problem Solving. Jurnal Inovasi Pendidikan Dan Sains, 1(2), 30-34. https://doi.org/10.51673/jips.v1i2.372.

Cakra, G., Dantes, N., \& Widiartini, K. (2016). Pengaruh Penggunaan Metode Pembelajaran Bermain Peran Terhadap Sikap Sosial Dan Kemampuan Berbicara Bahasa Indonesia Siswa Kelas Vi Sd N 29 Dangin Puri Tahun Pelajaran 2014 / 2016. Jurnal Penelitian Dan Evaluasi Pendidikan Indonesia, 5(1), 1-10. https://doi.org/10.23887/jpepi.v5i1.1579.

Daniel, E. (2016). The Usefulness of Qualitative and Quantitative Approaches and Methods in Researching Problem-Solving Ability in Science Education Curriculum. Journal of Education and Practice, 7(15), 91-100. https://doi.org/2222-288X.

Dharma, S., \& Siregar, R. (2015). Membangun Pengalaman Belajar Kewarganegaraan melalui Model Pembelajaran Project citizen pada Siswa. Jupiis: Jurnal Pendidikan Ilmu-Ilmu Sosial, 7(1), 100. https://doi.org/10.24114/jupiis.v7i1.2303. 
Din, M. (2020). Evaluating university students' critical thinking ability as reflected in their critical reading skill: A study at bachelor level in Pakistan. Thinking Skills and Creativity, 35(January), 100627. https://doi.org/10.1016/j.tsc.2020.100627.

Duriawati, A. D., Wasliman, I., Mulyanto, A., \& Barlian, U. C. (2020). Implementation of literation based learning information technology (study at MTs Alkasyaf, Mts Nurul Huda, and MTs El-Bas Ciamis). International Journal of Nusantara Islam, 8(2), 240253. https://doi.org/10.15575/ijni.v8i2.11338.

Fikriyah, F., Rohaeti, T., \& Solihati, A. (2020). Peran Orang Tua dalam Meningkatkan Literasi Membaca Peserta Didik Sekolah Dasar. Dwija Cendekia: Jurnal Riset Pedagogik, 4(1), 94. https://doi.org/10.20961/jdc.v4i1.43937.

Gusviani, E. (2017). Analisis Kemunculan Sikap Spiritual Dan Sikap Sosial Dalam Kegiatan Pembelajaran IPA Kelas IV SD Yang Menggunakan KTSP Dan Kurikulum 2013. EduHumaniora | Jurnal Pendidikan Dasar Kampus Cibiru, 8(1), 96. https://doi.org/10.17509/eh.v8i1.5127.

Harni, H. (2020). Meningkatkan Kemampuan Membaca Melalui Penerapan Pembelajaran Kooperatif Model Jigsaw Pada Siswa Kelas Iv Sdn 2 Uebone. Jurnal Pedagogy, 7(2), 108-114. https://doi.org/10.33394/jp.v7i2.2503.

Hidayat, M. C., \& Syam, A. R. (2020). Urgensitas perencanaan strategis dan pengelolaan sumber daya manusia madrasah era revolusi industri 4.0. Al-Asasiyya: Journal of Basic Education, 4(1), 1. https://doi.org/10.24269/ajbe.v4i1.2100.

Hidayati, N. N. (2020). Rethinking the quality of children's bilingual story books. AlAsasiyya: Journal Of Basic Education, 4(1), 46. https://doi.org/10.24269/ajbe.v4i1.2226.

Ikhwan, A., Farid, M., Rohmad, A., \& Syam, A. R. (2020). Revitalization of Islamic Education Teachers in the Development of Student Personality. 436, 162-165. https://doi.org/10.2991/assehr.k.200529.034.

Jamil, M. M. (2019). Optimalisasi Model ARCS Dalam Pembelajaran Saintifik Untuk Meningkatkan Motivasi Belajar Peserta Didik Pada Peminatan Mata Pelajaran Geografi Di Kelas Matematika Ilmu Alam. IJIS Edu: Indonesian Journal of Integrated Science Education, 1(1), 7-24. https://doi.org/10.29300/ijisedu.v1i1.1401.

Karadağ, R. (2014). Primary School Teacher Candidates' Views towards Critical Reading Skills and Perceptions of their Competence. Procedia - Social and Behavioral Sciences, 152, 889-896. https://doi.org/10.1016/j.sbspro.2014.09.339.

Khusniyah, N., \& Hakim, L. (2019). Efektivitas Pembelajaran Berbasis Daring: Sebuah Bukti Pada Pembelajaran Bahasa Inggris. Jurnal Tatsqif, 17(1), 19-33. https://doi.org/10.20414/jtq.v17i1.667.

Kim, M. C., \& Hannafin, M. J. (2011). Scaffolding Problem Solving in Technologyenhanced Learning Environments (TELEs): Bridging Research and Theory with Practice. Computers and Education, 56(2), 403-417. https://doi.org/10.1016/j.compedu.2010.08.024.

Marini, M., Sulha, S., \& Hartati, M. (2020). Keterampilan Menulis Naskah Drama pada Siswa Kelas XI IPA SMA Negeri 2 Sungai Kakap. EduIndo: Jurnal Pendidikan Bahasa Dan Sastra Indonesia, 1(2), 68-79. Retrieved from https://jurnal.fpbs.ikippgriptk.ac.id/index.php/eduindo/article/view/43.

Nurdiyanti, E., \& Suryanto, E. (2010). Pembelajaran Literasi Mata Pelajaran Bahasa Indonesia pada Siswa Kelas V Sekolah Dasar. Paedagogia, 13(2), 115-128. Retrieved from https://jurnal.fkip.uns.ac.id/index.php/paedagogia/article/view/153.

Purwaaktari, E. (2015). Pengaruh Model Collaborative Learning Terhadap Kemampuan Pemecahan Masalah Matematika Dan Sikap Sosial Siswa Kelas V SD Jarakan Sewon Bantul. Jurnal Penelitian Ilmu Pendidikan, 8(2), 95-111. Retrieved from 
https://journal.uny.ac.id/index.php/jpip/article/download/4932/4258.

Purwo, S. (2019). Peran Gerakan Literasi Sekolah Dalam Pembelajaran Kreatif Produktif di Sekolah Dasar. Journal of Chemical Information and Modeling, 53(9), 1689-1699. Retrieved from https://journal.stkippgritrenggalek.ac.id/index.php/kid/article/view/85.

Setyawan, A., Suwandi, S., Slamet, S. Y., Keguruan, F., Universitas, P., \& Maret, S. (2017). Muatan Pendidikan Karakter Dalam Cerita Rakyat Di Pacitan. Jurnal Pendidikan Karakter, 7(2), 199-211. https://doi.org/10.21831/jpk.v7i2.21778.

Sugiyono. (2012). Metode Penelitian Pendidikan (Pendekatan Kuantitatif, Kualitatif dan $R \& D$. Bandung: Alfabeta.

Suwartiningsih, Purwadi, \& Pusari, R. W. (2018). Upaya Meningkatkan Kemampuan Berbahasa Anak Melalui Metode Bercerita dengan Media Boneka Tangan pada Kelompok B di RA Al Muta'allimin Meteseh Tahun Ajaran 2017/2018. PAUDIA : Jurnal Penelitian Dalam Bidang Pendidikan Anak Usia Dini, 7(2), 50-60.

Tantri, A. A. S., \& Dewantara, I. P. M. (2017). Keefektifan Budaya Literasi Di Sd N 3 Banjar Jawa Untuk Meningkatkan Minat Baca. Journal of Education Research and Evaluation, 1(4), 204-209. https://doi.org/10.23887/jere.v1i4.12054.

Wijayanti, K. D., \& Sulaksono, D. (2019). Character Building for Early Childhood Learners Through the Shadow Puppet-Based Javanese Language Manners. Third International Conference of Arts, Language and Culture (ICALC 2018), 353-360. https://doi.org/10.2991/icalc-18.2019.50.

Wildan, W., Hakim, A., Siahaan, J., \& Anwar, Y. A. S. (2019). A stepwise inquiry approach to improving communication skills and scientific attitudes on a biochemistry course. International Journal of Instruction, 12(4), 407-422. https://doi.org/10.29333/iji.2019.12427a.

Windyariani, S., \& Sutisnawati, A. (2016). Pengembangan bahan ajar berbasis konteks dan kreativitas untuk melatihkan literasi sains siswa sekolah dasar. Jurnal Bioedukatika, $4(2), 19-25$.

Zahary, M., Bharata, H., \& Sutiarso, S. (2017). Pengembangan LKPD Menggunakan Pendekatan Multikultural Untuk Meningkatkan Kemampuan Pemahaman Konsep Matematika Dan Sikap Sosial Siswa. Jurnal Pendidikan Matematika Unila, 5(5), 4. Retrieved from https://core.ac.uk/download/pdf/295479718.pdf.

Zidoun, Y., El Arroum, F., Talea, M., \& Dehbi, R. (2016). Students' perception about mobile learning in Morocco: Survey analysis. International Journal of Interactive Mobile Technologies, 10(4), 80-84. https://doi.org/10.3991/ijim.v10i4.5947. 